\title{
Urdimento
}

Revista de Estudos em Artes Cênicas

E-ISSN: 2358.6958

\section{Palhaças e palhaços atuando em palcos hospitalares}

Entrevista com Wellington Nogueira concedida à Daiani Cezimbra Severo Rossini Brum

\section{Para citar este artigo:}

NOGUEIRA, Wellington. Palhaças e palhaços atuando em palcos hospitalares. Entrevista concedida à Daiani Cezimbra Severo Rossini Brum. Urdimento, Florianópolis, v. 2, n. 38, ago./set. 2020.

DOI: http:/dx.doi.org/10.5965/14145731023820200048 


\title{
Palhaças e palhaços atuando em palcos hospitalares
}

\author{
Wellington Nogueira entrevista concedida à \\ Daiani Cezimbra Severo Rossini Brum ${ }^{1}$
}

\begin{abstract}
Resumo
Este trabalho consiste na apresentação do artista cênico Wellington Nogueira, fundador da Associação Doutores da Alegria, e de entrevista cedida por ele transcrita na íntegra. O entrevistado narra o desenvolvimento e a inserção de figuras palhacescas profissionais em ambiente hospitalares, desde 1991. Promovendo a investigação de novas configurações espaciais no âmbito dos hospitais, e no campo da palhaçaria, assim como o estabelecimento de relações artísticas, humanas, políticas e sociais entre artistas e pessoas em situação hospitalar, esse fenômeno, a partir do projeto trazido ao Brasil por Wellington Nogueira, foi amplamente difundido no país, onde atuam contemporaneamente centenas de grupos.
\end{abstract}

Palavras-chave: Wellington Nogueira. Doutores da Alegria. Entrevista.

\section{Clowns acting in hospital stages}

This work consists of a presentation by the scenic artist Wellington Nogueira, founder of the Associação Doutores da Alegria, and an interview given by him transcribed in full. The interviewee narrates the development and insertion of professional clown in a hospital environment, since 1991. Promoting the investigation of new spatial configurations within hospitals, and in the field of clowning, as well as the establishment of artistic, human, political and social relations among artists and people in hospital situations, this phenomenon, based on the project brought to Brazil by Wellington Nogueira, was widely disseminated in the country, where hundreds of groups.

Keywords: Wellington Nogueira. Doctors of Joy. Interview.

\footnotetext{
Palhaça e doutoranda do Programa de Pós-Graduação em Teatro (PPGT/UDESC), Mestre em Artes Cênicas pela Universidade Federal do Rio Grande do Norte (2017), bacharel em Artes Cênicas pela Universidade Federal de Santa Maria (2012). Formou-se em palhaçaria na Escola de Palhaços dos Doutores da Alegria, no curso de Formação de Palhaços para Jovens (2014). Dedicou-se à atuação palhacesca hospitalar junto ao grupo Doutores Risonhos (Chapecó, SC, 2019), à criação artística autoral com a Cia Lunáticas de Palhaças (Florianópolis, SC, 2018-2020), às ações artísticas, teóricas, formativas e de pesquisa na área de Artes Cênicas. Tem experiência em interpretação teatral, máscaras, iluminação cênica, pesquisa e palhaçaria com ênfase na atuação de mulheres e nas poéticas dos contextos hospitalares. daianisevero@gmail.com
} 
Figura 1 - Wellington Nogueira ${ }^{2}$

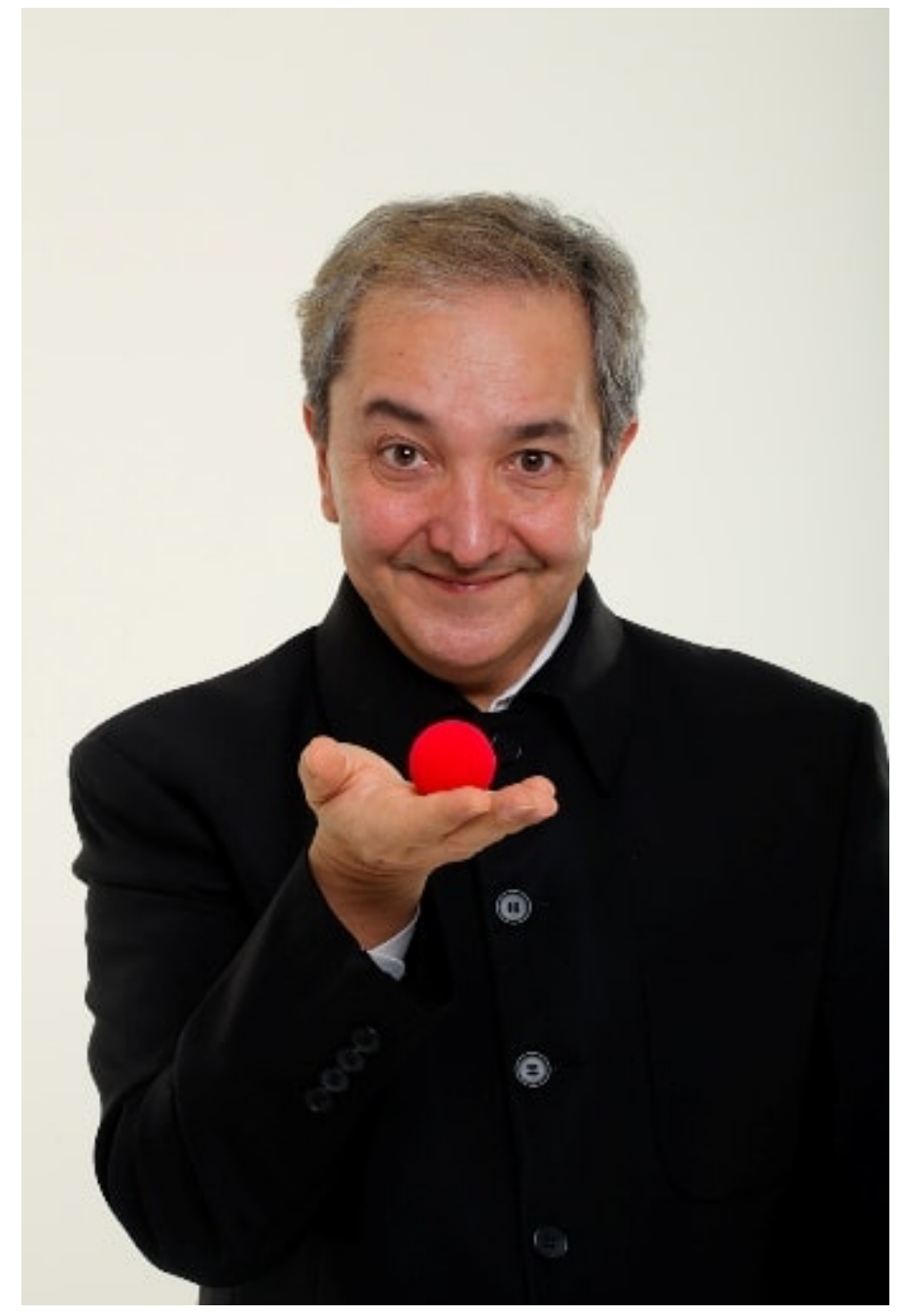

Fonte: Doutores da Alegria, 2020

Doutores da Alegria - Wellington Nogueira

A entrevista aqui apresentada realizada presencialmente no dia 31 de agosto de 2015, na sede de São Paulo (SP) dos Doutores da Alegria, como recurso metodológico, utilizado em minha pesquisa de mestrado, concluída em 2017³,

\footnotetext{
2 Fonte: https://doutoresdaalegria.org.br/blog/palestra-gratuita-com-wellington-nogueira/

${ }^{3}$ A pesquisa foi financiada pelo Fundo de Apoio a Pesquisa do Rio Grande do Norte (FAPERN) e resultou em uma dissertação de Mestrado em Artes Cênicas (UFRN).
} 
sendo que seu conteúdo foi gravado por áudio e transcrito. O objetivo do referido estudo foi investigar a atuação de palhaças e palhaços no contexto hospitalar a partir da reconfiguração de espaços e das relações cotidianas; da composição de um estado de jogo e abertura para os encontros teatrais. No decorrer da pesquisa, realizei algumas entrevistas com profissionais dos Doutores da Alegria, dentre eles, Wellington Nogueira, seu fundador e pioneiro na atuação profissional de palhaças e palhaços nos espaços hospitalares do Brasil.

Quando vi Wellington pela primeira vez, isto é, com exceção de sua imagem no filme Doutores da Alegria (2004), em 2013, estávamos em uma sala lotada por centenas de crianças, uma orquestra e um palhaço, o Doutor Zinho, vivido por ele. A audiência era ruidosa, animada e inquieta. Mesmo a orquestra com cerca de vinte musicistas não era páreo para o som promovido pela reunião entre as crianças na plateia teatral. Quando Wellington entrou em cena ecoou uma gargalhada pelo público. As conversas e brincadeiras entre amigas e amigos foram abrindo espaços, espontaneamente, para o riso, para o sorriso, para a observação atenta, para a interação com o Doutor Zinho. Wellington, brincando de regente da orquestra, conduziu a atenção das crianças. Após a chegada do palhaço permaneciam em estado de contemplação e envolvimento com as suas ações. Foi uma experiência impactante observar a destreza do artista, que sutilmente voltou toda a atenção de centenas de crianças em estado de alvoroço para o acontecimento cênico, estabelecendo com elas uma comunicação por meio da palhaçaria.

Tal situação reflete o oposto do contexto hospitalar, onde a audiência, muitas vezes, é composta por apenas uma pessoa, porém exemplifica a abertura do artista para a situação momentânea e seu trabalho de transformação do ambiente por meio da palhaçaria. A atuação da palhaça e do palhaço em Hospital é fundada na leitura das sutilezas do tempo real e, como exemplifica a atuação de Wellington, é capaz de treinar o olhar do artista, potencializando sua abertura para a relação com o público em outros espaços.

Investigando ao longo das últimas três décadas tal modalidade de atuação cênica e as suas relações com a sociedade civil, a Associação Doutores da Alegria 
atualmente tem atuação em São Paulo (SP) e Recife (PE). Os Doutores da Alegria contam com mais de quarenta palhaças e palhaços profissionais no elenco, além de equipe técnica e funcionários.

Nessa entrevista, Wellington conta sobre como se formou e inspirou junto ao Programa Clown Care , concebido por Michael Christensen, diretor do Big Apple Circus, organização circense de Nova lorque. "Wellington integrou a trupe de palhaços em 1988, satirizando as rotinas médicas e hospitalares mais conhecidas. Retornando ao Brasil, decidiu implantar um programa semelhante" (Doutores da Alegria, 2015, p. 01). Doutores da Alegria constituiu-se enquanto “[...] a única organização no mundo que evoluiu do trabalho no hospital para atividades que também priorizam a formação, a pesquisa e a geração de conteúdo para a sociedade".

A associação:

[...] é uma organização da sociedade civil, sem fins lucrativos, que tem como missão promover a experiência da alegria como fator potencializador das relações saudáveis por meio da atuação profissional de palhaços junto a crianças hospitalizadas, seus pais e profissionais da saúde. Além disso, a organização visa compartilhar a qualidade desse encontro com a sociedade com produção de conhecimento, formação e criações artísticas. (Doutores da Alegria, 2008, p. 07).

O grupo Doutores da Alegria “[...] promove a qualidade das relações humanas e qualifica a experiência de internação em hospitais por meio da visita contínua de palhaços profissionais especialmente treinados" (Doutores da Alegria, 2014, p.54). O trabalho da Associação, além de produzir grande impacto artístico e social no Brasil, também é reconhecido internacionalmente e foi incluído duas vezes pela Divisão Habitat da ONU entre as melhores práticas globais (Doutores da Alegria, 2014, p. 57). Em 2020 o grupo Doutores da Alegria foi homenageado pela Escola de Samba Dragões da Real, que teve como enredo "A Revolução do Riso: A Arte de

${ }^{4}$ O Clown Care é um programa comunitário da organização circense Big Apple Circus, e tem por objetivo levar a alegria do circo tradicional às crianças internadas em dezesseis centros pediátricos nos Estados Unidos. Um dos fundadores do Big Apple Circus, Michael Christensen cria o programa em 1986, baseado em seu desejo de oferecer um serviço exclusivo para jovens em tratamento, nas instalações pediátricas. (Big Apple Circus, 2015). 
Subverter O Mundo Pelo Divino Poder da Alegria”, o desfile aconteceu no Sambódromo do Anhembi, em São Paulo, e teve a participação de diversos profissionais dos Doutores da Alegria. Na imagem a seguir vê-se Wellington Nogueira e sua réplica carnavalesca em processo de construção.

Figura 2 - Wellington Nogueira e sua réplica

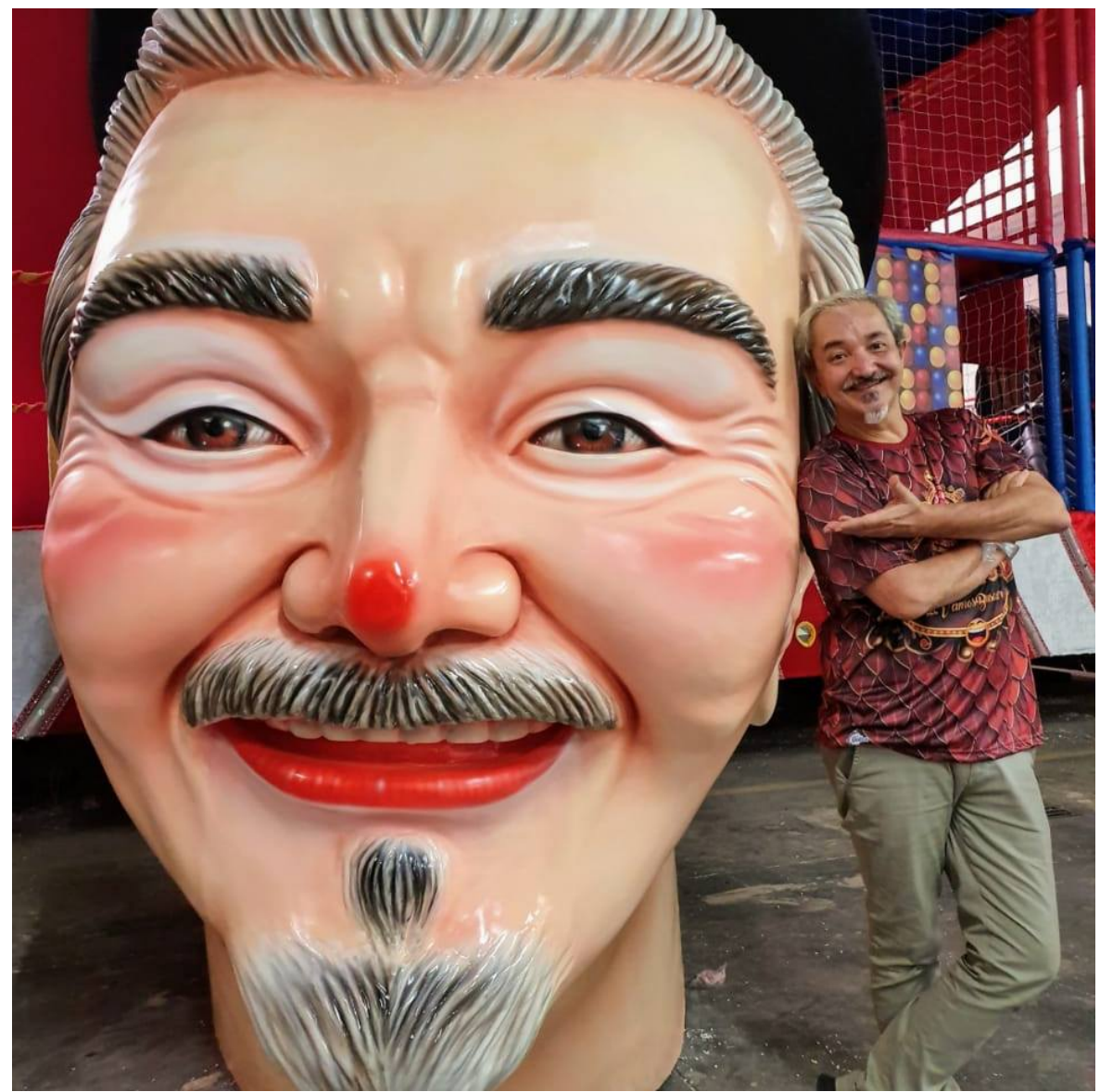

Fonte: Doutores da Alegria, 2020

Nas linhas que se seguem, abrem-se as alas para que se apresente a perspectiva de Wellington Nogueira, pioneiro na difusão da atuação de palhaças e de palhaços no contexto hospitalar brasileiro. Nesta entrevista, junto ao Wellington criador, dá-se uma narrativa que registra parte da trajetória do artista, completamente ligada com a sua obra: os Doutores da Alegria. 


\section{Wellington, você poderia falar um pouco sobre as experiências artísticas que the moveram até o contexto hospitalar e sobre como essa prática se desenvolveu até os dias de hoje na sua vida? Pode contar um pouco desta história?}

Eu sempre quis ser ator. Eu era daqueles caras que faziam teatrinho no fundo do quintal no fim de semana. Então, eu queria ser um artista completo e na minha cabeça, ser um artista completo era ser um cara que dança, canta e representa. E, para mim, o referencial era a Broadway, então eu falei:

- Quer saber? Eu vou para Nova Iorque estudar Teatro Musical, porque lá estão os grandes mestres em comparação com Londres, que têm uma produção também bem forte. Mas o musical americano, para mim, era mais desafiador, porque ele realmente busca colocar em cena o artista completo, que canta, dança e representa, fazendo bonito nas três áreas. Então, eu fui buscar isso, agora na minha primeira semana de aula (risos), estava lá: Palhaço. Eu pensei: oi? Como assim? Teatro Clown, eu vim para a Broadway, eu não vim para o circo.

Eu tinha uma noção muito distorcida e errada do trabalho de palhaço como sendo a última opção da escolha de carreira na vida de alguém. Então, eu brinco que ser palhaço não é uma escolha de carreira, era resgate Cármino. Se você foi muito ruim em uma vida passada, você volta como palhaço. Não me passava pela cabeça ser palhaço, porque eu era muito ignorante. Quando eu comecei a estudar, eu perguntei, por que agente tem de estudar palhaço no Teatro Musical? E eles responderam que era porque o Musical rompe com a realidade, com a quarta parede a partir do momento em que você fala com a plateia, que você está em uma cena em que a emoção está tão forte que você irrompe em canção, então é uma ruptura com uma realidade para criar outra, e o palhaço faz isso com muita tranquilidade. Quando eles me deram esta explicação, eu fui para a aula.

Quando eu fui para a aula, encontrei e vivi uma liberdade que não sabia que tinha, e pude ver que eu era engraçado. Sempre fui um cara bem humorado, e nas minhas aulas sempre utilizei o humor, mas fazia isso de modo amador. Um cara engraçado, mas graça para o palco não tinha noção que eu tinha. Então, o trabalho com teatro clown começou no Teatro Musical, mas ele acabou tendo um peso 
muito importante na minha vida, porque ele me mostrou tantas coisas que eu não sabia que tinha e que eu não sabia que existiam. Acabei me envolvendo muito com o meu professor e me tornando um pouco o seu aprendiz.

Quando me formei, meu professor me convidou para trabalhar. Eu trabalhei com ele dois anos, durante dois espetáculos; trabalhando com outros palhaços, pude ter uma imersão no mundo de palhaçaria. Por sorte, este professor era um cara muito da prática, mas também um acadêmico, então ele tinha o lado de pesquisa e um acervo muito forte, organizava um festival de palhaçaria. Esta relação com o mestre me embasou muito para pensar os Doutores. Eu me formei. É como se você tem uma paixão extraconjugal, a minha esposa era o Teatro Musical, o palhaço, apesar de todo este potencial, estava no armário, eu não queria ser palhaço, jamais, nunca. Eu nunca investia um dia da minha vida procurando ser palhaço, era sempre uma forma, um recurso para eu ser um melhor artista cômico de Teatro Musical, porque também no processo de aprendizado no Teatro Musical, recebi este retorno: "Você tem que fazer comédia porque você é engraçado, e isso não é todo mundo que consegue”. Eu pensei: Ok, vamos nessa!". Bom, estou lá em Nova Iorque desenvolvendo minha carreira, conseguindo trabalhos como ator; enfim, sabe quando a vida está rolando? Mas, eu senti um buracão. Não era tão divertido quando eu fazia teatrinho no fundo do quintal. Nessa época, em Nova Iorque, uma amiga me chamou e falou que estava precisando de um palhaço que fale espanhol. Eu falei:

- Mas você sabe que eu não sou um palhaço. Ela falou:

- Você é um palhaço, sim! Você só não sai do armário. Eu falei:

-Tudo bem! Vou fazer essa gentileza.

O meu preconceito todo caiu por água abaixo quando eu fui para o hospital. Porque primeiro eu vi uma dupla, eu achava que ia ver uma dupla sacarina de palhaços, que queriam ter uma história bacana para contar para a família no jantar, sabe? Eu sou muito crítico, e, enfim, achava a ideia estapafúrdia. Quando eu cheguei ao hospital, a primeira coisa que me surpreendeu foi a força, você vê dois palhaços, com um jaleco branco, porque eles realmente promoviam uma 
interrupção muito grande, na frequência. Era como que você pensasse: "Oi? O que foi aquilo que eu vi?”. E quando você vai parar para pensar, eles já sumiram. Segui a dupla, que eu tinha combinado de segui-la, e, logo no primeiro quarto, o que eu vi foi muito marcante, porque me lembro de que era uma menina de uns nove ou dez anos, bem prostrada no leito, quando eles chegaram à porta.

Eles não entraram no leito dela, apresentaram-se. Quando eles chegaram, a enferma fez isso (gesto de esquivar-se), mas quando ela viu quem estava na porta, já fez isso (gesto de curiosidade); eles da porta se apresentaram: " Eu sou Doutor Fulano, Doutora Fulana. Como vocês sabem estamos aqui no hospital e só queremos fazer uma esterilização, uma coisa simples, não pode ter micróbios e tal”. E ele (o palhaço) começou a soltar bolhas de sabão; como um mágico habilidoso, que era também, com aquelas bolhas de sabão, começou a fazer truques de mágicas, completamente fascinantes.

Eu fiquei completamente enredado nas mágicas e outra parceira dele era engraçadíssima; a menina foi ganhando tônus, sentou no leito e foi ficando fascinada com aquilo. E por que ela estava fascinada com aquilo? Porque os artistas não eram nem um pouco bonzinhos, eles não eram legais, eles eram competentes, profissionais, limpos, sabe? Tão técnicos como mágicos, você não os via fazendo a mágica. Não era rasteiro, não era assim uma boa ação, encobrindo dois artistas mais ou menos que não têm nada melhor para fazer e estão lá no hospital ganhando um trocado. Não era realmente isso.

Tinha uma excelência no trabalho deles, uma limpeza, que você via que era de gente que tem muita competência, e isso me arrebatou. Quando eles pediram licença para entrar, e ela disse "sim, sim, sim", saindo da cama, aquilo me arrebatou também, porque até hoje eu não vi este impacto sobre uma plateia de uma pessoa. Algo que sempre aprendi no teatro e no cinema é que uma plateia de uma pessoa só é um fracasso retumbante, mas no hospital não é. No hospital significa cem por cento de sua lotação. Então, para mim, foi como se abrisse um portal infinito, dentro de um universo, com o qual eu era extremamente familiarizado, mas eu nunca tinha olhado por este viés; o trabalho me arrebatou tanto, que me deu medo. Eu liguei para minha amiga que me convidou para fazer 
o teste e falei que não poderia fazer, porque eu era só um ator de Teatro Musical. "Para você fazer isto você tem que ser muito bom. E você sabe que eu não investi minha vida em me tornar um bom palhaço". Então, ela falou:

- Pare de choramingar, eu te dou três meses para você se preparar.

Ok. Então, eu fui. Como ela me deu esse tempo, eu aceitei o desafio. Pensei:

“Como vai ser meu palhaço? Meu clown Médico?” Então, eu pensei que tenho uma relação muito crítica com a Medicina. Para mim, a Medicina é um jogo de tentativa e erro, o cara não confessa isso para você. Ele se apresenta como o infalível, o cara que tem as respostas e as soluções e no final é tudo muito ridículo. Percebi que tinha um olhar crítico sobre essa situação e levei isso para o meu teste. O teste, eu fiz com o palhaço que criou este trabalho. Então, primeiro a gente se aquece com os outros artistas, com os outros palhaços, e depois eu ia trabalhar com o 'cara' que tinha criado, Michael Chistensen.

Nós fomos a três quartos. No primeiro, eu mais apoiava e ele que segurava a onda; no segundo, a gente ia meio a meio; e no terceiro, eu tinha que mostrar o que eu tinha criado. Desde o primeiro quarto foi muito mágico, porque eu vi nele um grande artista, generosíssimo, muito senhor do seu talento e da sua habilidade, muito simples. Ele fazia graça e humor com o que estava ali na frente dele, com o que ele estava vendo. A atitude de jogo cênico dele foi tão generosa, que, justamente, ele foi abrindo espaço para jogar.

No segundo quarto, foi ficando melhor, eu fui mais seguro. Eu me lembro de que, como médico palhaço, diagnosticava o óbvio sempre: "Você está com dor de cabeça? Entendo! É muito importante você saber que na sua cabeça existe um par de olhos, separados por um nariz, e abaixo deste nariz tem uma boca”. Então eu falava, falava e falava e não mudava nada a situação. Pensei: “Bom, eu já estou preparado para este terceiro quarto, porque eu vou entrar com esse esquema, que já deu certo". Quando entramos, era um moleque de uns sete ou oito anos na ortopedia, ele tinha gesso do peito até a cintura, tinha uns ferros saindo deste gesso, parecia um aro de bicicleta. E ele (Michael Chistensen) falou: 
- Neste quarto, você vai mostrar o que preparou.

E eu tinha preparado todo um lance de ser um grande cultivador do óbvio e do medíocre. Então, eu detectava o problema, "olha, você está me enxergando bem, você está me ouvindo bem”, aquelas coisa básicas, perguntas básicas. Quando eu vi o gesso do menino, eu falei: "Este gesso talvez esteja muito pesado. Então, nós temos que pensar em alguma coisa que traga um pouco mais de leveza, se não para o gesso, para você". Mas você vê, eu fui tratar do gesso, já era um pouco do meu pensamento, o médico vai tratar aquilo que é mais fácil de tratar, ou seja, o gesso do que o paciente. E eu sei dizer que o Michael foi me apoiando, então, por exemplo, eu falava:

- Vamos fazer o exame? E ele falava:

- O resultado já está aqui.

Eram cartõezinhos com hieróglifos. Eu sei dizer que a gente riu muito com aquilo, e a impressão que eu tive foi de que a gente tinha ensaiado aquilo uma semana de tão perfeito. O timing dos três, da construção daquela cena, foi feita uma única vez. E quando eu estava saindo, o menino me chamou de novo e falou:

- Doutor! Muito obrigado! Eu estou me sentindo muito mais leve.

Sete anos, você está entendendo? Aquilo me arrepiou inteiro, eu nunca tinha vivido nada igual. Eu não fui para o hospital para ser um bonzinho ou um bom samaritano. Eu fui para ser um artista competente. E, muito embora, não tivesse as habilidades da mágica e do malabares, que são todas as habilidades circenses que os colegas que eu assisti mostraram tão lindamente, eu tinha uma mente engraçada, uma formação teatral, eu cantava, mas nem me passou pela cabeça cantar no hospital porque eu também não tocava nenhum instrumento, o que eu tocava muito mal era a flauta. Enfim, eu era um equívoco.

Então, mas eu vi que com os recursos que eu tinha e com o que eu tinha criado, dava resultado, e como eu te falei, eu não fui para ser bonzinho, criou-se ali uma cena entre aquelas três pessoas, uma cena que teve um impacto sobre a plateia de um, mas outra coisa que me chocou também foi o impacto dessa plateia de um teve em mim. Essa é uma relação com o teatro que eu não estava 
habituado. O pessoal te aplaude. Nossa, legal, você foi muito bem, eles te aplaudem de pé, mas o que você fez na vida deles? O que eles fizeram na sua? Você nunca sabe. Mas, no hospital, eu pude até querer ter uma ideia de como eu podia ter impactado aquela criança, mas nunca eu tinha visto o outro lado de como aquela criança me impactou.

Para mim foi um universo novo, que eu compreendia como arte. Porque o que a gente fez foi arte pura, improvisação, construção de cena, conflito, estava tudo lá. Isso me provocou tanto, que eu comecei a pensar: " poxa vida, como que é? Como que foi?". E na medida em que eu fui trabalhando, fui entendendo isso. Eu também fui treinado e o Michael me deu um retorno, ele disse: "Olha, você entendeu direitinho a essência deste trabalho". Eu falei: “ yeah, vamos começar a trabalhar!"

Comecei o trabalho, fui treinado, e tudo o que fui entendendo foi isto, tinha uma nova referência. Aprendi que o teatro era a caixa preta; me lembro do Gabriel Vilela falando, olha uma que é uma caixa preta vazia que na hora que agente está lá dentro com uma intenção clara, sabendo o que agente quer saber, o espaço se torna habitado por nós e pelos deuses do teatro, e não duvidem deles porque eles existem. Então, eu tinha toda essa cultivação pelo palco, e, de repente, eu me vi dentro de uma UTI, tocando vida e tendo minha vida tocada, e com cenas que eram construídas comigo e com meu colega, porque a gente trabalhava em dupla.

Existiam cenas que eram completamente criadas pelas crianças. A criança dava o mote da improvisação; outras eram por nós; outras a gente ia construindo juntos. Eu falava que era um teatro fora do teatro. Então, eu fui vivendo, me especializando e me tornei outro tipo de artista, porque no teatro convencional ou em um musical, a história é "eu saio de casa todos os dias para provar para aquele diretor que eu sou o ator certo para aquele papel”. É sempre um jogo, uma loteria, onde, na maior parte das vezes, você não acertou os números. Eu vi que gostava muito de criar, e quando entendi a formação de palhaço, eu fui me tornando um, e mais importante, eu tinha uma visão bidimensional do palhaço, que era me vestir de palhaço e entrar em cena e fazer algo. 
O hospital, sair do espaço sagrado do teatro, para mim, eu vi como o que acontece, quando acaba a peça e você não tira a maquiagem e você sai do palco e você se encontra com a plateia no ponto de ônibus ou no metrô. A vida continua e tudo mais. Para mim, aquilo trouxe todos estes questionamentos e campos de visão. Que teatro é este que eu estou fazendo? Há alguns anos com o advento da internet, que trouxe a expressão tempo real, eu disse cara, é isso. Eu estou cocriando uma cena com meu parceiro e com meu outro parceiro de cena, que é a criança em tempo real. É isso. Um roteiro com começo, meio e fim, criado em tempo real, pela criança e pelo palhaço. Essa autonomia criativa para mim é arrebatadora.

A outra autonomia, eu vinha experimentando como palhaço, à medida que eu me especializava individualmente como palhaço, convivendo com outros palhaços e trabalhando no hospital, eu fui ganhando estofo. Então, eu vi que quando você sai do ambiente protegido do picadeiro e do palco, e vai para a vida real, você começa a virar de carne e osso; e eu acho que, hoje, qualquer ator, principalmente palhaço, que fica só no picadeiro ou só no palco, tem ainda um pouco mais de liberdade porque ele costura as cenas e trabalha totalmente no improviso, mas ainda, o público pagou ingresso para ver você. Aqui eu estou fazendo o caminho inverso, eu estou pedindo licença para entrar na sua vida em um momento de intimidade. Então, eu não posso nem ser bonzinho e nem ser meia boca. O mínimo que eu tenho que fazer é ser muito bom, porque você está me dando sua confiança. Essa relação ficou muito clara, o que estava em jogo era muito claro. Parece qualquer coisa, mas não é. Existe essa força e esse compromisso, porque a gente pedia permissão para entrar e, uma vez que, se entrava, não era sobre submeter à criança a nenhuma Performance, mas estar a serviço da criança para construir junto com ela uma Performance.

Começou a se delinear ali para mim toda uma estrutura. Tenho muita tranquilidade em falar que foi com o advento dos Doutores aqui, com o trazer os Doutores para cá (Brasil), que eu fui aprofundando um pouco mais este pensamento, esta prática e escrevendo a respeito, porque é outra forma, é uma intervenção cênica na vida real, para construção de cenas. É dramaturgia da vida 
real. Tanto que se você assistir ao nosso documentário, têm vários relatos, como a história do duende, do encontro de uma dupla de palhaços com a morte, e você vê muitas outras.

Imagina para você enquanto artista, ir de encontro a sua plateia e ser autorizado a fazer parte de momentos de extrema intimidade e de respeito. Descobri o sagrado da Arte Cênica, da Performance, porque para mim isso era arrebatador e eu nunca tinha visto ou vivido nada igual. Por isto, eu falava que era uma profissão de futuro. Estão formando o artista do futuro, e o hospital é um ponto de partida; mas quais são as outras instituições e lugares aonde você pode criar isto, consumir isto, viver isto? Eu fui fazer teatro porque eu amava o risco do ao vivo, mas eu lidava com esse risco após dois meses de ensaio, oito horas de ensaio por dia, cenas, marcas, figurinos, o luxo de você ter um diretor olhando você e te dando retorno, quer dizer, toda uma estrutura criada para te jogar na vida real, e te jogar no contato com o público, mesmo assim, você vê, dependendo do que você está fazendo ali no palco, a sua relação com o seu colega, mas a sua plateia é muito mais espectadora do que qualquer outra coisa; no hospital não, quebrou todas as barreiras, vieram todas as licenças, e isso para mim revelou um novo palco.

Então, todos os dias eu chegava a casa e estava criando cenas, querendo aprender outras coisas. Era um diálogo porque essa relação era algo que se retroalimentava. Não era só eu indo lá fazer o meu trabalho, pegando meu cheque e voltando para casa. Para mim, foi o que representou e o que me motivou até hoje a fazer isso e aprofundar isso. E criar o FPJ (Formação de Palhaços para Jovens) $)^{5}$, preparar jovens artistas. Eu tenho a tranquilidade de que essa aposta se pagou porque hoje cada vez mais a gente está vendo isso acontecer. O teatro, para mim, ainda é um templo, ainda é um espaço sagrado, mas o que eu aprendi com isso, é que quando você tem dois artistas muito tranquilos e seguros no que eles estão fazendo, como eles estão fazendo, o templo pode ser reproduzido em

${ }^{5}$ O Programa de Formação de Palhaços para Jovens foi implementado pelos Doutores da Alegria no ano de 2004, e, novamente, situou a ONG em situação de pioneirismo, pois foi a primeira iniciativa de um programa contínuo para palhaços na América Latina. O PFPJ forma vinte e cinco jovens com vulnerabilidade social em palhaços, a cada dois anos, e solidificou a Escola de Palhaços dos Doutores da Alegria. 
qualquer lugar, em qualquer circunstância da vida, inclusive, a cotidiana, para justamente provocar nela uma ruptura e aí poder entrar a arte, entrar outra forma de ver o mundo de se relacionar com a vida.

Como você visualiza este trabalho hoje, após estes vinte e quatro anos de atuação dos Doutores da Alegria? E quais são os impactos, a partir desta ruptura no cotidiano, pensando também no surgimento de grupos com trabalho inspirado nos Doutores?

Depois deste monólogo, né? (risos). Eu acho que o Doutores inspirou muita gente, não é? Hoje são mil e oitenta pessoas e sete programas semelhantes pelo Brasil. Eu tenho muita tranquilidade em falar que eu ainda acho que o Doutores tem o pessoal mais bem preparado, mas tem muita gente muito boa fazendo um belo trabalho. O que mais me alegrou foi que ao fazer a escolha de não virar as costas para estes semelhantes e ficar na zona de conforto de taxá-los como cópias mal feitas, covers; a gente trouxe eles para perto, a gente falou: "Quer fazer isso? Então, vamos fazer direito" e, a partir, do momento que a gente trouxe essa dimensão do que significa este trabalho, muita gente mudou, muita gente se profissionalizou, entendeu a missão.

Isso me dá uma alegria e orgulho muito grandes, porque eu entendo que a arte vem para tocar sua vida, para ser um farol, para te mostrar novas possibilidades. Na mitologia, Zeus cria as musas, as artes para o homem entender o que é transcendência, imortalidade; o que é ser Deus, entusiasmo E eu encontrei tudo isso no trabalho do hospital. Então, quando você vê outras pessoas vivenciando isso, se comprometendo com isso, levando para o próximo passo.

Eu tive um senso de responsabilidade muito grande, porque eu sabia que eu estava começando este negócio. Com todo este profissionalismo, eu não sabia se seria fácil ou difícil, mas eu tinha uma preocupação de não banalizar o trabalho para que a gente não corresse o risco de alguém fazer algum trabalho "porco" e o hospital falar que é prejudicial, “Vocês tem que sair daqui!”. Para mim, a dimensão deste trabalho era uma coisa tão forte e tão sagrada, que eu falava: 
- Você já pensou se eu entrar para história como o cara que ferrou com este trabalho no Brasil? Eu vou responder eternamente por isso.

Então eu tenho até hoje um medo muito grande, mas não é um medo paralisante, é um medo de ouvir com cuidado, e isso eu aprendi com o palhaço que criou o trabalho, Michael (Chistensen) que dizia que o trabalho sabe para onde ele quer ir, você só tem que ouvir e sair do caminho para não atrapalhar. Eu sempre usei isto como máxima. Hoje, eu vejo essa contribuição em vários aspectos, no sentido de você fomentar a arte do palhaço no Brasil, de uma maneira que acho que é incontestável. Quando eu comecei a estudar a história do palhaço, e descobri que ele vem de uma linhagem muito fascinante de rupturas.

O palhaço, na verdade, é uma manifestação de um arquétipo milenar que é o arquétipo do bobo e este arquétipo, ele tem várias formas de materialização na história da humanidade, seja como um bobo da corte, um palhaço no circo, uma figura xamânica, uma divindade que vem para bagunçar, numa dimensão folclórica quando você vê, por exemplo, o Curupira ou o Saci Pererê, todas essas figuras vêm para bagunçar as percepções do homem; o Curupira confunde os caçadores para salvar os animais.

De certa forma, o palhaço dentro do hospital está fazendo o trabalho dele, a arte dele, a palhaçada, e, completamente, integrada no contexto em que ele está visitando; e ele está, sim, alterando a percepção das pessoas lá dentro. Ele causa um impacto na vida daquelas crianças, e, hoje, especificamente, hoje, eu posso falar para você, vou te mostrar esta foto aqui (mostra uma foto de um jovem vestido de palhaço). Este é um jovem estudante de Medicina de Ribeirão Preto, vai fazer Oncologia Pediátrica, é o que ele quer fazer, teve leucemia e de 1999 até 2001, foi visitado pelos Doutores da Alegria duas vezes por semana, o impacto foi tão grande na vida dele para passar por aquele momento, que olha como ele está devolvendo o que ele vivenciou com agente? Para que serve a arte? E quando eu vejo isto aqui... não é ele. Tem muitos casos assim, a coisa fica maior. Então, a gente viu muita gente querendo fazer este trabalho inspirado nos Doutores. Hoje, existe um legado que é um congresso chamado "Medicina, cultura e arte", feito por estudantes de Medicina e Enfermagem, se encontrando uma vez por ano para 
discutir sobre como colocar mais arte no seu procedimento médico. Se você for ver a história deste arquétipo, do bobo, ao longo da história da humanidade, muitas vezes a figura dele se cruza com a figura do curador, porque o pajé faz todo um borogodó ali para entender você, abrir um canal de comunicação entre você e a doença, você e sua enfermidade.

Não é para acabar com ela, mas é para ouvir, dialogar e brincar com ela; para você poder ver que história vocês vão escrever juntos. Isso é muito potente. Este cara, esta figura do bobo da corte, do menestrel, ele fazia muito parte da vida das pessoas. O circo funcionou como um ventre de lona, porque ele gestou este tipo de artista, que é o palhaço, que a gente conhece com o nariz vermelho.

O confinamento trouxe um refinamento técnico para este artista, mas eu entendo que, em 1986, ele sentiu falta daquele contato direto de fazer parte da vida das pessoas, porque antes do teatro e do circo, a arte era na rua: você cruzava com os artistas no caminho de casa, e isso podia marcar você para sempre. Então, eu vejo que houve um refinamento da sociedade e houve um refinamento deste artista. Em 1986, ele sai do circo, não para abandonar aquele ventre, mas para tornar aquele ventre mais amplo, e o primeiro lugar que ele encontra é o lugar onde estão as crianças hospitalizadas e faz a humanidade com esta ação se aproximar e pensar, e tão forte que ela começa a se globalizar. Isto para mim é um sinal muito claro e concreto de um movimento, de uma necessidade contemporânea, sendo suprida pelo resgate de um arquétipo milenar, através da arte.

A saída do palhaço hoje do circo é uma questão sócio-cultural muito forte. Ele vem fazer uma ruptura no seu cotidiano e, assim, agindo, permite que você se emocione, acesse emoções, percepções, que é isto que arte pode fazer. Se você for ver o contexto social hoje, com o advento de tecnologias, traz a humanidade para uma ampliação de seu conhecimento, e, ao mesmo tempo, uma regressão nas capacidades relacionais. Somente na relação com o outro, você é capaz de enxergar também a sua relação com você mesmo. Qual é papel desse arquétipo ao longo da história da humanidade? Buscar o outro ponto de vista, buscar o lado menos visitado, menos explorado, avisar, comentar, ser um crônico. Então, quando 
o palhaço sai do hospital e, a partir dele, eu venho colecionando inserções de palhaços em áreas de desastres. Em escolas, em empresas, é um novo mercado, um mundo inteiro que se torna com as suas instituições, uma série de novos palcos, que precisam ser habitados, e, por isso, o comprometimento com criar uma escola, para poder formar esses artistas, para que eles possam interferir levando a arte.

\begin{abstract}
Muito Obrigada, Wellington. Você foi passeando pelas questões, que nada mais eram, para nós, do que ouvir um pouco das suas experiências e como você lida hoje com este trabalho, que você iniciou aqui no Brasil. Você gostaria de fazer mais alguma colocação?
\end{abstract}

Eu queria dizer que este artista é um artista popular; ele é sempre a voz do povo. Ele até se refina quando vai, por exemplo, servir um Henrique VIII, mas ele é a voz do povo, justamente, o cara que transita. Eu fui ficando cada vez mais consciente do trabalho e desta dimensão que ele tinha e como eu te digo, ela é muito daqui (Brasil), sabe? Porque no exterior não tem ninguém desenvolvendo um trabalho como a gente está desenvolvendo, com esta seriedade e com esta profundidade. E eu não falo isso para me gabar, falo porque eu acho que o que me favoreceu foi estar em um Brasil que não estava pronto e estava, numa época de mudança e tinha tudo para ser feito e uma predisposição muito grande. Então, eu pude pirar, visionariamente, e o Brasil está me aceitando. E me lembro de que quando eu falei:

- Eu quero ser escola.

O primeiro público que a gente quis servir foi justamente o de jovens que tivessem o talento e a vontade, mas não necessariamente as condições para poder fazer esse estudo. Tenho muito orgulho do FPJ e fico mais orgulhoso ainda quando a gente tem um diálogo como este, porque alguma coisa deve ter acontecido aqui que sensibilizou a sua percepção e que tá te mobilizando a escrever a respeito e é esta maravilhosa falta de controle, que está germinando, olha só, os desdobramentos que vão voltando. 
Eu me sinto um cara de muita sorte por ter tido acesso a tudo isto, então eu penso que tenho que compartilhar, e eu quero começar compartilhando com quem quer e não sabe como ir. Para mim, todas estas dimensões que foram se abrindo e que a gente não pode perder esta oportunidade e nem banalizar o trabalho. Se a gente banalizar o trabalho, se a gente não trouxer esta dimensão de valor, acho que aí a humanidade pode perder uma bela oportunidade de evolução, de crescimento.

Hoje, o que estou juntando de histórias, do passado até aqui, e, juntando um pouco com a capacidade de olhar para o futuro, nós estamos passando por uma série de mudanças, e o palhaço é um arquétipo que transita na mudança; agora você me vê, agora você não me vê, ele transita com tranquilidade, porque ele habita cada momento. Eu tenho a ousadia de achar que este movimento global, ele tem total potencial de ajudar a humanidade a fazer esta transição; aparar uma próxima fase que é uma fase mais consciente, mais sustentável, menos mecanicista, uma fase onde a arte tem que está muito mais presente no cotidiano do ser humano. É isto que eu tinha para falar, muito obrigado por me ouvir.

\section{Referências}

BIG APPLE CIRCUS (Estados Unidos). Clown Care Program. Site da organização Big Apple Circus. Disponível em: <www.bigapplecircus.org/clown-care>. Acesso em: 01 mai. 2020.

DOUTORES DA ALEGRIA (São Paulo). Boca Larga: cadernos dos Doutores da Alegria número 4. São Paulo, Doutores da Alegria: 2008.

DOUTORES da alegria: o filme. Direção de Mara Mourão. Produção de Fernando Souza Dias. São Paulo: Mamo Filmes, 2004. DVD (96min), color.

DOUTORES DA ALEGRIA (São Paulo). Sobre os Doutores: mais de duas décadas de trabalho. 2015. Disponível em: <www.doutoresdaalegria.org.br/conheca/sobre-osdoutores>. Acesso em: 01 mai. 2020.

DOUTORES DA ALEGRIA (São Paulo). Balanço 2014. São Paulo, São Paulo. Doutores da Alegria: 2014. 
Recebido em: 06/05/2020

Aprovado em: 25/05/2020

Universidade do Estado de Santa Catarina - UDESC Programa de Pós-Graduação em Teatro - PPGT Centro de Arte - CEART Urdimento - Revista de Estudos em Artes Cênicas urdimento.ceart@udesc.br 